\title{
Interview with Amos Paran, Specialist in L2 Reading and Literature in Language Teaching
}

\section{D} r. Amos Paran teaches MA and $\mathrm{PhD}$ students at the University College London's Institute of Education. Fluent and literate in English, Hebrew, and German himself (with a bit of Spanish and French), he is probably best known for his research and writing on literature in foreign language learning. Among

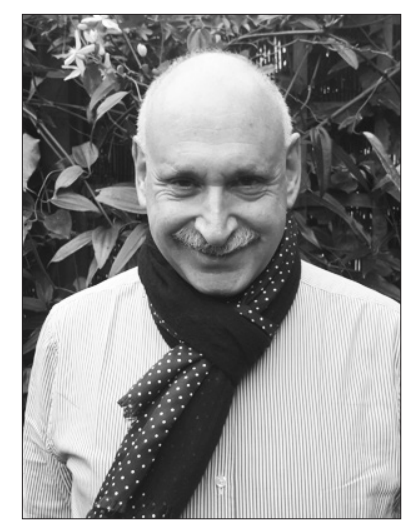
the recent books he has written, edited and co-edited are Literature - Into the Classroom with Pauline Robinson (2016), Testing the Untestable in Language Education (Multilingual Matters, 2010) with Lies Sercu, and Literature in Language Teaching and Learning (2006, TESOL).

Simon Bibby and Anna Husson Isozaki: Thank you for agreeing to this interview. Much of your writing has focused on literacy and literature in the EFL language classroom. How did you become an advocate of literature in language teaching?

Amos Paran (Paran): We really need to backtrack. I did a BA in English Literature and Linguistics, and I took a teaching diploma as an insurance policy, because I was going to be engaged in literature. One of the poems on the syllabus was W.H. Auden's Musee des Beaux Art (1938). It's a wonderful poem, which he wrote in 1938. It starts, "About suffering they were never wrong, the old Masters: how well they understood its human position" (p. 34). For my test lesson I taught that, and without knowing it, I devised a lesson that was task-based. I didn't know that there was such a thing as 'task-based learning'; at that time there wasn't-it was 1979. And the lesson went swimmingly. I still use that lesson, and it's in my latest book. The poem is based on the painting, The Fall of Icarus, by Bruegel. Most people would start with, "Let's read the poem, let's talk about the poem," and then say, "Oh, by the way, let's look at the painting," and I put it upside down, and said, "Let's look at a painting. What do you see?" We'd discuss the painting, and at some point they would see Icarus ... We would talk about Icarus, then I would say, "Oh, okay, let's look at a poem." So the whole thing was upside down. And it's always been an amazing success. So, that was my test lesson. From the very beginning of my work I was teaching poetry and using poetry.

In my teaching diploma class there was somebody who was teaching in a school that needed a teacher for an afternoon course for students who were proficient in English and exempt from EFL classes, a course that would focus mainly on literature. I started teaching them and I found out I loved it, and then I was offered a full-time post in that school, teaching EFL. Literature was always an important part of what we did. I used to read aloud in class ... I remember I was reading Arthur Miller's All My Sons (1947), and the bell rang. I closed the book and said, "Okay, we'll continue tomorrow," and the class responded, "No, no, no, please go on reading!" These things don't happen to you when you're doing other stuff. These things happen to you when you are doing literature.

So basically I became an advocate based on two things, really. One is my own love of literature, my engagement with literature, my love of reading. And the second one is that literature goes to places you don't get to when you talk about other things. We talked about politics, important things ... But literature is the thing people actually remember and take with them.

SB \& AI: What general advice would you give to teachers who are putting together a curriculum centered around literature?

Paran: Well, my first advice would be: Don't be afraid. The basic condition of humans is a love of literature and literary artifacts. There is not one 
person who does not love literary artifacts. They may not know it! But they do. Who doesn't love songs? Songs are also literary artifacts. I used to teach American Pie, which is an incredibly rich piece with elements of intertextuality, requiring background knowledge. What was "The day the music died"?

So, don't be afraid, everybody loves literature. There's always something that your learners will like. Start easy. You don't have to come in and start with Shakespeare. Although, having said that, a lot of my students in secondary school were so proud they'd read a sonnet by Shakespeare, in English. "Wow! Look at me!" There are fantastic Robert Frost poems, there are fantastic short poems by other poets-there's so much.

I suppose l've come to my second point, which is: Choose wisely-choose things that will work with your class. Choose things that you think your class will like.

The next principle is: Choose something that you like. You've got to convey your passion for the work. The most important thing is to like the literature -it's the affective response, going back to Louise Rosenblatt (1983). All you need to do is lead the horse to water....

Don't be afraid, choose wisely, choose easy stuff, choose things that you think they will love, choose things that you love, and if your learners don't like something, drop it. Do you know Daniel Pennac's The Rights of the Reader (2006) with illustrations by Quentin Blake? One of the rights of the reader is not to read, so if they don't like something, stop it.

Give your learners choice. Can you incorporate choice? Have a mixture of genres, and if things are long, don't dwell too much on anything - the most important thing is enjoyment. They've got to enjoy it. Otherwise there's no point.

SB \& AI: Can literature fit into the communicative classroom?

Paran: I think there's a problem: Teachers don't get trained in teaching literature. They get trained to do language and jigsaws and all sorts of interesting stuff in teacher training programs. When you get to literature, there are two things that happen. One is, teachers think, "Oh, but do I know enough about literature?" And, "Can I really teach it?" Teachers lack confidence about teaching literature. People very often, when they come to teach literature, even wonderful, communicative people, suddenly stand there and pour in knowledge, become transmitters because "it's important that you should know this, it's important that you should know that." I don't see it that way. I think you can do a lot of communicative stuff with literature. Most of the things that I do are tasks that the students need to do as preparation for the piece of literature. They make lists, they produce something tangible - they do it in pairs, they discuss it-and there's a lot of language learning.

So there's absolutely no contradiction. It takes more thinking, it's more difficult, you need to find an appropriate task for a text. The learners need to experience how great it is, so the teacher needs to find a task that will help them experience it. I work a lot with paintings and with visual art and with musicall ways of enhancing the learners' experiences.

SB \& AI: What would you like to see change in EFL?

Paran: The big thing l'd like to talk about is what is known in education as a whole as "the apprenticeship of observation." It was a term coined by the sociologist Dan Lortie in 1975 in a book called Schoolteacher (2002). Lortie makes an astute observation. If you're going to become a teacher, you have spent most of your life observing teachers. From the moment you went to kindergarten, reception, nursery or whatever, until you graduate from university you have spent 13,500 hours observing teachers in the classroom, seeing what teachers do. You come in and you think that is what teaching should be.

Many of us learned foreign languages through grammar-you study the rule before you see examples. A lot of us succeed that way ... and a lot of us don't. But people who succeed then go on to become teachers. Even if they didn't like it, it's there. They walk into the classroom, they do their communicative stuff, something goes wrong and they fall back onto what they know from before. Part of the problem is teachers fall back on teacher-centered frontal teaching, and they don't even know it. There are teachers who think they are learner-centered because they ask a question and the student has to answer. That's not being learner-centered. And for me the thing that teachers have to learn and have to understand is how to relinquish control. It is being the guide on the side rather than the sage on the stage. It's very difficult being the guide on the side when you look at something and you want to intervene and be the sage on the stage. It's very easy to fall into that trap. Partly, it is also because your students expect that. So you're working against the expectations of your students, and against your own experience. It takes a long time to be able to relinquish the control and work with your students on how they can take control of their own learning. The systems are not set up for that. Teach students to take control of their own learning. You have to 
find a space where your learners live, and learn, and take on the responsibility for learning.

SB \& AI: Recently, you've been discussing reading literature aloud. In fact you wrote in previous email correspondence with us that "... listening to literature read aloud is important in developing the connections between the phonological representation and the visual form of the word. And of course reading aloud is something that is far more natural to literature than to other texts." Can you tell us a little more about this?

Paran: Reading aloud is interesting-it's important for a variety of reasons. Part of our language competence is the link between the phonological representation of the word and the visual representation of the word, and the meaning. In fact, you can't read a word without the phonological representation being activated. So reading aloud serves to strengthen that link between the phonological representation and the visual, orthographic representation, and that's important. If a work is slightly above the level of the student, if the teacher reads it aloud, that's parsing it for the students, breaking it into chunks, using intonation, thereby helping them create a vision of what it's about.

I think reading aloud is not the easiest thing to do-and in fact I remember when I did my teacher training we had a session on reading aloud and how to read aloud, and l've since worked with practicing teachers on this skill, and on how to develop it. When you read aloud to a class, you can't have your face stuck in the book. You've got to read and look at the students, because that way you're communicating to them. Otherwise it looks as if you're reading aloud to yourself. It's really, really important, and not easy.

There's the question of whether the learners should read aloud. A lot of teachers get their learners to read aloud. I think there's an issue there. Reading aloud something that you've never read before is very difficult. So asking learners to do that, I think is slightly problematic. I would say, "Get your learners to prepare a dramatic reading of a piece of literature." If you are not sure of reading aloud, there are audiobooks. I did a lot of work with The Curious Incident of the Dog in the Night-Time (Haddon, 2003) -it's a really interesting novel. I did it in Chile in a teacher training workshop, and I wanted them to read as fast as possible, and so I put the audiobook on for about fifteen, twenty minutes. We listened to it, and they read along in their books.

Another point is that reading aloud is part of life for many people, as Sam Duncan from the UCL
IOE has shown (Duncan, 2014a, 2014b). People read aloud to their partners: bits of a book, or bits of the newspapers. It can be an important part of language teaching, but it's got to be handled with care in my view.

SB \& AI: A criticism of using ungraded authentic literature is that the texts are too difficult and they should be graded by vocabulary level. How do you respond?

Paran: I think we very often give our learners things to read that are too difficult in terms of progressing reading, sight vocabulary, and fluency. You need to read something that is below the level you're at. Readers really need to know most of the words in the text, as Batia Laufer (1992) has shown. I think the percentage Paul Nation (1990), Bill Grabe (2002) and others quote now is $98 \%$. Otherwise you stop. If you're trying to enjoy a book, if you've got more than two or three unknown words per page, you're not going to enjoy it, and if these words are crucial, then you won't understand it. If you're reading for pleasure you're going to put it aside.

When you're doing extensive reading, I'm a real believer in "read easy and read a lot." It's more important to read a lot at a low level than to struggle with something that is above your level or even at your level, but you need to work hard to understand it. If you want to get flow, if you want to get enjoyment, it's got to be easy. Csikszentmihalyi's point about flow (1990) is that you've got to do something that will be slightly challenging. In terms of reading, in terms of language, I'm not sure about it. I think the language needs to be non-challenging. Maybe the content can be interesting and challenging, but the language itself-if the language becomes challenging most of us wouldn't go on. You would have to have a very high level of interest in the subject.

SB \& AI: What are you working on these days?

Paran: I'm doing a number of things. Andrea Révész and Myrrh Domingo and I have just finished recording and constructing a MOOC, "Teaching EFL/ESL Reading: A Task Based Approach." A book has just come out, Literature-Into the Classroom, with Pauline Robinson (Paran \& Robinson, 2016). I'm editing a book on Shakespeare in the language classroom, and l've just edited a special issue of the ELT Journal on language teacher associations, because I'm quite active in IATEFL.

I am also working on a big study of literature in language teaching, across a variety of languages, for the International Baccalaureate organization (an international body offering programs of school study) 
together with Sam Duncan (e.g., Duncan (2014a, 2014b) on adult literacy and reading for pleasure). We've interviewed teachers and students, observed classes and recorded classes. We've got interviews with about 25-30 teachers, in three different schools in three different countries, and we're looking at what they say about literature in language teaching, the role of literature in language learning and acquisition, and the advantages of using literature in the language classroom.

SB \& AI: Well, you certainly are a busy man. Thank you very much for the interview and for your time.

\section{References}

Auden, W. H. (1938). Musée des Beaux Arts. Another time. New York: Random House.

Csikszentmihalyi, M. (1990). Flow: The psychology of optimal experience. New York: Harper \& Row.

Duncan, S. (2014a). Reading for pleasure and reading circles for adult emergent readers. Leicester, UK: NIACE Publications.

Duncan, S. (2014b). Reading aloud in Lewisham: An exploration of adult reading-aloud practices. Literacy $9(2)$, 84-90.

Grabe, W., \& Stoller, F. (2002). Teaching and researching reading. Harlow, UK: Longman.

Haddon, M. (2003). The curious incident of the dog in the night-time. London, UK: Jonathan Cape.

Laufer, B. (1992). How much lexis is necessary for reading comprehension? In P. J. L. Arnaud \& H. Bejoint (Eds.), Vocabulary and applied linguistics (pp. 126-132). London, UK: Macmillan.

Lortie, D. C. (2002). Schoolteacher: A sociological study. Chicago: University of Chicago Press.

Miller, A. (1947). All my sons: A play in three acts. New York, NY: Reynal \& Hitchcock.

Nation, I. S. P. (1990). Teaching and learning vocabulary. New York, NY: Newbury House.

Paran, A. (2006). Literature in Language: Teaching And Learning (Case Studies in TESOL Practice Series). Alexandria, VA: TESOL.

Paran, A., \& Robinson, P. (2016). Into the classroom: Literature. Oxford, UK: Oxford University Press.

Paran, A., \& Sercu, L. (2010). Testing the untestable in language education. Bristol, UK: Multilingual Matters.

Pennac, D. (2006). The rights of the reader (S. Ardizzone, Trans.). London, UK: Walker Books.

Rosenblatt, L. M. (1983). Literature as exploration (4th ed). New York: Modern Language Association. (Originally published 1938).

\section{Additional Suggested Reading}

Paran, A. (1996). Reading in EFL: Facts and fictions. ELT Journal, 50(1), 25-34.

Paran, A. (2008). The role of literature in instructed foreign language learning and teaching: An evidence-based survey. Language Teaching, 41, 465-496.

Simon Bibby is a faculty member at Kobe Shoin Women's University. He is currently a doctoral student at Liverpool University. His research interests include effective use of educational technologies for language learning, and using literature in language classes. He founded the Literature in

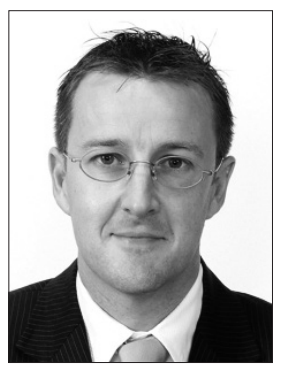
Language Teaching (LiLT) SIG to meet and learn from other people in Japan who use literary texts in their classes, and started the Journal of Literature in Language Teaching (JLiLT) as a place to share ideas in this area. Outside of academia, he is now returning to competitive international chess after a hiatus of several years.

Anna Husson Isozaki teaches at Juntendo University in Tokyo. She holds an MA in Advanced Japanese Studies from Sheffield University UK, a Journalism certificate from the University of Massachusetts, Amherst MA, and an MA TESOL from Kanda University of International Studies. Her research interests

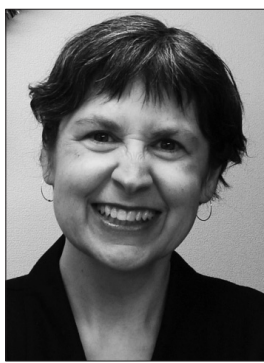
are mainly focused on second language literacy, orature, translation, and critical media literacy. She has been slipping literature into EFL classrooms in Japan for twenty years, and bringing Japanese literature to the West by co-translating two bestselling Japanese novels and editing several more.

\section{BizCom SIG}

\section{Business \& Intercultural Negotiation Conference}

\author{
Kansai University \\ July 1 \& 2, 2017
}

Call for Presentations

http://jalt.org/bizcom/index.html 